\title{
Article \\ Experience of Using Antifungal Rocima GT for Protection of Paper from Biological Damage Caused by Fungi
}

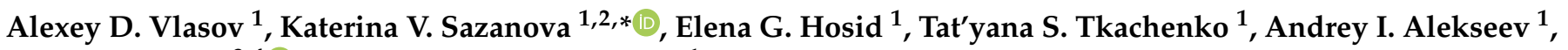 \\ Ivan M. Pchelin ${ }^{3,4}$ (D) and Alexandr A. Galushkin ${ }^{1}$
}

1 Laboratory of Conservation and Preservation of Documents the Archive of the Russian Academy of Sciences, St. Petersburg Branch, 196084 St. Petersburg, Russia; alex_vlasov@mail.ru (A.D.V.); lenahosid@gmail.com (E.G.H.); 233286anton@mail.ru (T.S.T.); lkrd@rambler.ru (A.I.A.); lkrd1934@mail.ru (A.A.G.)

2 Analytical Phytochemistry Laboratory, V.L. Komarov Botanical Research Institute of Russian Academy of Science, 197376 St. Petersburg, Russia

3 Scientific and Educational Center "Molecular Bases of Interaction of Microorganisms and Human" of the WCRC "Center for Personalized Medicine", Institute of Experimental Medicine, 197376 Saint Petersburg, Russia; arcella.oraia@gmail.com

4 Kashkin Research Institute of Medical Mycology, North-Western State Medical University Named after I.I. Mechnikov, 194291 St. Petersburg, Russia

* Correspondence: barinova-kv@mail.ru; Tel.: +7-9-65-078-9312

Citation: Vlasov, A.D.; Sazanova, K.V.; Hosid, E.G.; Tkachenko, T.S. Alekseev, A.I.; Pchelin, I.M.; Galushkin, A.A. Experience of Using Antifungal Rocima GT for Protection of Paper from Biological Damage Caused by Fungi. Appl. Microbiol. 2022, 2, 185-196. https://doi.org/ 10.3390/applmicrobiol2010013

Received: 29 December 2021 Accepted: 23 February 2022 Published: 26 February 2022

Publisher's Note: MDPI stays neutral with regard to jurisdictional claims in published maps and institutional affiliations.

Copyright: (C) 2022 by the authors. Licensee MDPI, Basel, Switzerland. This article is an open access article distributed under the terms and conditions of the Creative Commons Attribution (CC BY) license (https:// creativecommons.org/licenses/by/ $4.0 /)$.

\begin{abstract}
This study proposes a method for the chamber disinfection of paper with biocide in the form of fine, volatile droplets using antifungal Rocima GT. This method provides a fungicidal effect, and within a short exposure time, a fungistatic one. At a concentration of $5 \%$ Rocima GT solution, the minimum treatment time to ensure the complete disinfection of paper was $15 \mathrm{~min}$. The proposed method of disinfection by a chemical mist was less harmful to paper than disinfection using a swab saturated in a biocide solution. It was noted that when using Rocima GT at insufficient concentrations to inhibit fungal growth completely, Rocima GT can induce, as well as suppress, organic acid produced by Aspergillus niger depending on the concentration.
\end{abstract}

Keywords: Aspergillus niger; biodeterioration; organic acids; paper; biocides; Rocima GT

\section{Introduction}

Biodeterioration caused by microscopic fungi is a significant problem affecting different construction materials and buildings, but the threat of biological destruction is especially alarming for the preservation of the historical and cultural heritage of museum archives and libraries [1-5]. Due to their enormous enzymatic activity and their ability to grow at low water-activity values, fungi are able to inhabit and decay paintings, textiles, paper, parchment, leather, oil, casein, glue, and other materials used for historical art objects [6]. The great majority of these fungal species are already able to develop at water activity levels near 0.80 , which qualifies them as xerotolerants. Regarding temperature, the optimum growth levels are about $20-25^{\circ} \mathrm{C}$, a common interval for human comfort in libraries, archives, and museums [5].

Most of the micromycete species found in archives and libraries are ubiquitous species, but they are able to grow in conditions different from in nature. When placed in favorable conditions, their germination and development can occur very quickly. The combination of the high bio-receptivity of paper with inappropriate storage conditions or extreme situations associated with water damage makes the material very susceptible to microbial contamination, mainly by fungi $[3,7,8]$. The bio-receptivity of paper for fungi is considered high due to its hygroscopicity and composition (cellulose, hemicellulose, adhesives, and sizing), which is an abundant source of carbon for fungi [3,7]. 
The fungi can produce cellulolytic enzymes which break the cellulose polymer into smaller units, weakening the paper structure. Acidic metabolites can be excreted by these microorganisms, promoting acid hydrolysis in the paper fibres. In addition, they can excrete coloured metabolites with several different hues, having the potential to blemish the documents and artworks where they dwell. The release of all these extracellular enzymes and/or pigments acts chemically on the substrate [5].

Paper-based cultural heritage kept in museums and libraries can show notorious signs of deterioration, including foxing stains, caused by fungal colonization [9].

$A$. niger is one of the very viable and harmful species of micromycetes frequently found in archives and libraries and in museums on paper and cellulose textiles [5,6]. Moreover, A. niger is known as a producer of organic acids [10], which cause the rapid and deep destruction of various materials [5,11-15]. The overproduction of citric acid is a characteristic feature of $A$. niger. In addition to citric acid, $A$. niger also produces a number of other acids $[10,16,17]$.

In addition to the harmful effect on materials, a high degree of contamination of premises with fungal spores can cause allergic reactions, dermatoses, mycoses, and SBS (Sick Building Syndrome), and some species can induce serious lung diseases [5,18-21]. The fungi that most often cause allergic symptoms belong to the genera Alternaria, Cladosporium, Aspergillus, Candida, Penicillium, Mucor, Fusarium, and Rhizopus [22], as well as Aspergillus niger and some other species [23].

The level of contamination is naturally correlated to dust accumulation, and one can argue that this can be prevented with maintenance [5]. Preventive measures are fundamental in the field of biological document security [24]. In the storage areas of libraries and museums, certain precautions should be taken, such as limited lighting, a low temperature $\left(16-18{ }^{\circ} \mathrm{C}\right)$, and relative humidity in the range of $40-55 \%[6,25,26]$.

However, there are situations when documents are seriously damaged and require urgent disinfection processing. Moreover, fungal growth mostly happens between shelves with little aeration or near walls with temperatures below the dew point. Micro-niches are often also created by the wrapping of single objects into extremely tight boxes, not allowing an exchange of air and vapor [6]. There is a wide selection of antifungal substances with different chemical compositions and principles of action. A proper antifungal treatment method of materials should have a broad activity spectrum, good chemical stability, low cost, no adverse effects on the treated material, and be non-toxic to humans. [3,25,27].

Traditional antifungal methods usage may increase the risks of developing drug resistance. Therefore, the development of non-toxic and safer antifungal strategies to treat the fungal biodeterioration of paper products is still an important task and remains a challenge [27].

This issue is most problematic in the case of the mass disinfection of archival collections; when a large number of documents need to be processed, fumigation methods are preferable. Substances traditionally used for the fumigation of documents (formaldehyde, ethylene oxide, methyl bromide, and thymol) have a number of disadvantages that make further use inadvisable, with toxicity to humans and negative effects on document materials being the main ones [3]. In France, for some years, thermal fogging with an alkyl dimethylbenzylammonium chloride solution has been employed successfully for the cleansing of an atmosphere contaminated by fungi [28]. Over the last 10 years, chemical misting methods using disinfection based on quaternary ammonium salts [26], as well as silver nanoparticles [29], have shown their effectiveness in museums, archives, and libraries for protection against microbiological contamination.

Nevertheless, there is little research on chemical misting today, and its usage in conservation is limited. It is important to note that the heating involved in most of these developments may adversely affect the properties of some biocides.

This study proposes a method for the chamber disinfection of paper by the antifungal Rocima GT using ultrasonic action without additional heating. 
Rocima GT is an antifungal used for different types of materials, including plasters, textile, and paper. This antifungal is a mixture of chlormethyl-/methylisothiazolone, a quaternary ammonium compound, formaldehyde, and a formaldehyde donor. Rocima GT provides very good bacterial and fungal control [30]. The studies of Rocima GT for use in archives and libraries indicate its efficacy and safety for historical papers. Rocima GT is relatively safe for humans and has a pronounced antifungal activity at a minimum concentration of $0.5 \%$ [31].

The aim of this work was to evaluate the effectiveness of Rocima GT against Aspergillus niger using an application of a traditional swab treatment and the new means of aerosol disinfection in chambers. An analysis of the effect of Rocima GT on the production of organic acids was one of the tasks of this study.

\section{Materials and Methods}

\subsection{Fungal Strain Isolation and Identification}

For the experiments, we used Aspergillus cf. niger strain P3.17. It was isolated from paper-based documents in 2014 in Saint-Petersburg. The strain was stored in test tubes cultured on Czapek Dox Agar at $12{ }^{\circ} \mathrm{C}$.

Morphological species identification was carried out with the use of guidebooks $[32,33]$. Molecular identification was performed by Sanger DNA sequencing of the locus TEF $1 \alpha$. To isolate genomic DNA, we took fungal spores by cotton swabs and processed them with GeneJET Plant Genomic DNA Purification Mini Kit (Thermo Fisher Scientific, Lithuania) according to the manufacturer's protocol. DNA amplification was performed with the use of EF1-1018F (5'-GAYTTCATCAAGAACATGAT-3') and EF1-1620R (5'-GACGTTGAADCCRACRTTGTC-3') primers [34]. The amplification program was $94{ }^{\circ} \mathrm{C}$ for $30 \mathrm{~s}, 48{ }^{\circ} \mathrm{C}$ for $45 \mathrm{~s}$, $72{ }^{\circ} \mathrm{C}$ for $1 \mathrm{~min}$. The PCR products were purified by precipitation in acidified isopropanol with the addition of glycogen and sequenced on both strands using BigDye Terminator v3.1 Cycle Sequencing Kit (Thermo Fisher Scientific, USA) on a 3500 Genetic Analyzer (Thermo Fisher Scientific, Waltham, MA, USA).

\subsection{Fungal Cultivation and Paper Inoculation}

Before undergoing Rocima GT treatment, a sample of experimental paper was inoculated with $A$. niger suspension $\left(0.1 \mathrm{~mL}\right.$, conidia concentration $\left.1 \times 10^{4}\right)$.

Three types of test papers were taken for all experiments:

B-5-82 g/ $\mathrm{m}^{2}, 100 \%$ sulfite cellulose, ash content-5\% (filler-kaolin);

B-19-82 g/ $\mathrm{m}^{2}, 100 \%$ sulfate cellulose, ash content- $5 \%$ (filler-kaolin);

B-25-85g $/ \mathrm{m}^{2}, 100 \%$ bleached cotton half-mass, ash content-9\% (filler-kaolin).

In the case of studying the biocidal effect by the method of swab and treatment in a chamber, in addition to experimental paper samples with specified compositional parameters, commercially produced, typographical printing paper was also used. Typographical printing paper contains equal parts cellulose and wood pulp and 15\% kaolin. The physical and mechanical parameters of this paper have not been tested.

After treatment in the chamber or by a swab saturated in Rocima GT solution, samples of paper with spores of $A$. niger were placed in Petri dishes on the Czapek-Dox nutrient medium. The samples were incubated at $25^{\circ} \mathrm{C}$ for 1 month. The radial growth rate was assessed by the diameter of the colony. The experiments were carried out in triplicate.

In order to investigate the effect of Rocima GT on the fungal resistance of paper during storage, the paper samples exposed to a cold mist of Rocima GT were stored in paper envelopes at $40 \%$ relative humidity and room temperature. After 2 months, the samples were placed on a nutrient Czapek-Dox medium in Petri dishes, inoculated by $A$. niger, and incubated at $25^{\circ} \mathrm{C}$ for 15 days.

In order to determine the composition of organic acids in the cultural liquid, the cultivation of fungus was carried out on a liquid Czapek medium (g/L: glucose -20; $\mathrm{NaNO}_{3}-2.0 ; \mathrm{KH}_{2} \mathrm{PO}_{4}-1.0 ; \mathrm{MgSO}_{4} \bullet 7 \mathrm{H}_{2} \mathrm{O}-0.5 ; \mathrm{KCl}-0.5 ; \mathrm{FeSO}_{4} \bullet 7 \mathrm{H}_{2} \mathrm{O}-0.01$ ) in static conditions at $25^{\circ} \mathrm{C}$ (volume- $50 \mathrm{~mL}$ ). The cultivation time was 8 days. 
The effect of Rocima GT on the growth of $A$. niger in liquid culture was determined by weighing of dry biomass of mycelium.

\subsection{Rocima GT Treatment}

2.3.1. The Treatment of the Inoculated Paper Samples with Rocima GT

Paper samples were treated by Rocima GT solution by two means: traditional methods using a swab and by cold mist in a special chamber.

\section{Swab Treatment}

The samples of paper were carefully blotted with a gauze swab moistened with a biocide solution. Aqueous solutions of a biocide concentration of 0.5 and $2 \%$ were used.

\section{Treatment in Chamber}

The Rocima GT aqueous solution was aerosolized into a cold mist using ultrasonic action to avoid negatively affecting the active substance with heat. This method allows the aqueous solution to be converted into a state of fine droplets due to high-frequency vibrations. For the experimental study of Rocima GT, the cold mist's antifungal activity, and its effect on the mechanical properties of paper, a special chamber (volume $80 \mathrm{~L}$ ) was constructed. This chamber was connected by an adapter tube to a vessel filled with Rocima GT 5\% aqueous solution (1 L), in which ultrasound generators were placed. Three generators (power $24 \mathrm{~W}$ ) were used at the same time. The chamber was filled with Rocima GT solution mist for three minutes. In this case, the approximate amount of liquid transferred to the state of mist was $50 \mathrm{~mL}$, which corresponded to approximately $625 \mu \mathrm{L} / \mathrm{L}$.

In order to select the optimal disinfection time, paper samples contaminated by $A$. niger spores were fumigated by Rocima GT for 5, 10, 15, 20, 25, and $30 \mathrm{~min}$.

\subsubsection{The Cultivation of Aspergillus niger, Medium Enriched with Rocima GT}

To study the effect of Rocima GT on the organic acids produced by $A$. niger, the biocide was added to the medium in concentrations $0.01 \%, 0.05 \%$, and $0.1 \%$.

\subsection{Organic Acids Analysis}

\subsubsection{Sample Preparation}

In order to determine the content of organic acids in the culture broth of $A$. niger, an aliquot of the culture broth $(10 \mathrm{~mL})$ was acidified with $0.1 \mathrm{M} \mathrm{HCl}$ to $\mathrm{pH} 1.0$ to dissolve insoluble salts. Then, this aliquot was diluted by distilled water and was passed through a cation exchanger (KY-2-8 C) to free the acids from their salts. The resulting aqueous solution of organic acids was evaporated at $40{ }^{\circ} \mathrm{C}$. The dried extracts were dissolved in pyridine $(30 \mu \mathrm{L})$ and BSTFA (N, O-bis-3-methyl-silyl-3-F-acetamide) (30 $\mu \mathrm{L})$ and incubated at $100{ }^{\circ} \mathrm{C}$ for $15 \mathrm{~min}$.

\subsubsection{Gas Chromatography-Mass Spectrometry}

The derivatized samples were analyzed by gas chromatography-mass spectrometry (GC-MS) on a Maestro instrument (Interlab, Moscow, Russia) with an Agilent 5975 massselective detector (Column HP-5MS, $30 \mathrm{~m} \times 0.25 \mathrm{~mm} \times 0.25 \mu \mathrm{m}$ ). Chromatography was performed with linear temperature programming from $70{ }^{\circ} \mathrm{C}$ to $320^{\circ} \mathrm{C}$ in the mode of constant carrier gas flow through the column $(1 \mathrm{~mL} / \mathrm{min})$; the carrier gas was helium. Mass spectra were scanned in the range of $50-750 \mathrm{~m} / \mathrm{z}$ with a frequency of $1.6 \mathrm{scans} / \mathrm{s}$. Chromatograms of the samples were recorded using the total ion current. Mass spectrometric information was processed and interpreted using the AMDIS program [35], standard NIST2005 library, and the library of standards compounds of BIN RAS. Quantitative interpretation of chromatograms was performed by the internal standard method using tridecane in the UniChrom program [36]. 


\subsection{Estimating the Physical Characteristic of Paper}

The effect of the Rocima GT treatment on the mechanical and physical properties of the paper was assessed by the change in the values of the fracture resistance index. The measurements were made on the device "I-1-3" (Russia) for determining the fracture strength with multiple kinks [37]. The tests were carried out in 10 repetitions in the longitudinal and transverse directions. Three types of test papers were the same as the ones used for inoculation by fungi (B-5, B-19, B-25). Heat aging of the test paper samples was carried out in the thermostat «EKROS ES-4610» at $105^{\circ} \mathrm{C}$ for $72 \mathrm{~h}[38,39]$.

The measurements of whiteness were made on the device "photoelectric spherical photometer FMSh-56M" (Russia) [40]. The tests were carried out in 10 repetitions.

\subsection{Statistical Analysis}

Statistical analysis was performed via the Student's $t$-test using Microsoft Excel and Origin Pro software.

\section{Results}

\subsection{Fungal Species Identification}

The obtained TEF1 $\alpha$ sequence of $A$. niger isolate P3.17 was deposited in a GenBank with the accession number MH029907. It was used for a MegaBLAST search against the fungal sequences of the NCBI Nucleotide database. The top score hits included the A. niger, A. welwitschiae, and A. awamori sequences. To refine the identification, we aligned the TEF1 $\alpha$ sequence of the isolate P3.17 with sequences of well-annotated Aspergillus strains [41,42]. The studied sequence was identical in A. niger ITEM 4501 (FN665404) and A. welwitschiae CBS 139.54b (QQZQ01000062.1:113618-114218). Based on the combined results of morphological and cultural studies, the strain was identified as Aspergillus niger Tiegh.

\subsection{Evaluation of the Viability of A. niger after Treatment by Rocima GT}

First, four types of experimental paper, B5, B 19, and B 25, and typographical printing paper inoculated by $A$. niger, were treated with a 0.5 and $2 \%$ Rocima GT solution by swab. A treatment by swab provided a good antifungal effect at both concentrations for 15 days. On the 30th day, weak growth of $A$. niger was observed on only one sample of the typographical paper treated by the $0.5 \%$ Rocima GT solution. In the control samples without treatment, the growth of mycelium began on the second day after the inoculation of the spore suspension.

In the case of the chamber treatment, after a week of incubation of the paper samples on a nutrient medium, the growth of the mycelium of $A$. niger was not observed in any of the experimental paper samples (Figure 1). On the 15th and 30th days (Figure 2), growth was observed on all samples (B5, B 19, and B 25, and the typographical printing paper) treated for $5 \mathrm{~min}$ and in one sample treated for $10 \mathrm{~min}$ (growth rate was 30-50\% less than in the control). There was no significant difference in the growth rate of fungi depending on the type of paper.

After treatment by the Rocima GT and storage for two months, the paper samples were reinoculated by $A$. niger; the antifungal effect of Rocima GT was absent for all types of paper.

\subsection{The Influence of Rocima GT on the Physical Properties of Paper}

The comparison of the effect of the Rocima GT mist on the strength and whiteness of paper with an aqueous solution (applied by swab) of $0.5 \%$ and $2 \%$ (Table 1 ) showed that the greatest negative effect on the mechanical strength of the paper appeared to be the treatment with a $2 \%$ water solution of Rocima GT. The treatment of paper by a $0.5 \%$ aqueous solution of Rocima GT, as well as treatment by a mist of $5 \%$ aqueous solution of Rocima GT, affected the strength of paper made of sulphite cellulose (B-5) and cotton (B-25) in the same way. For paper made of sulphate cellulose (B-19), the average value of the fracture resistance after treatment with the $0.5 \%$ aqueous solution of Rocima GT decreased by $8 \%$ more than after treatment with Rocima GT "vapors." 


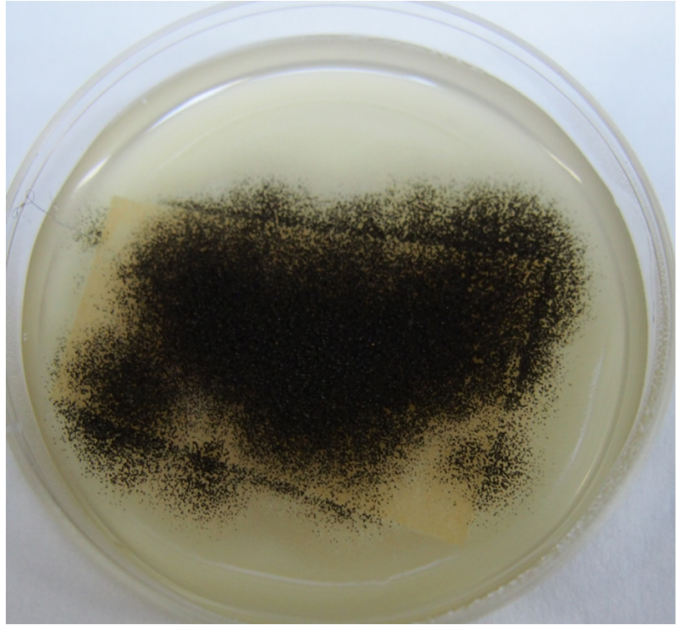

(a)

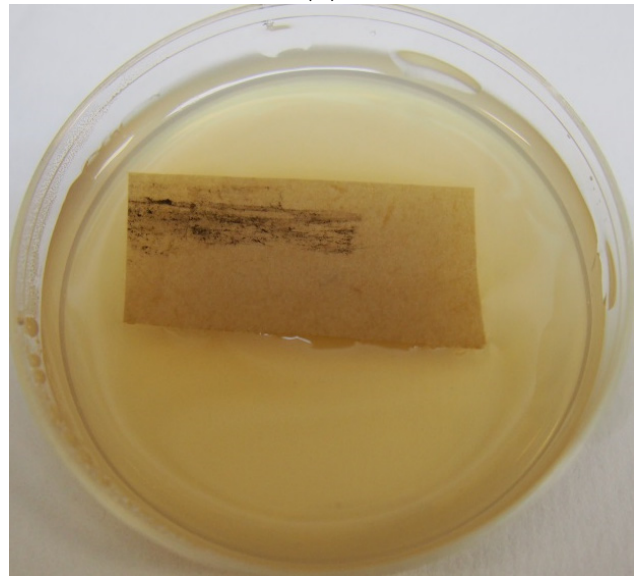

(c)

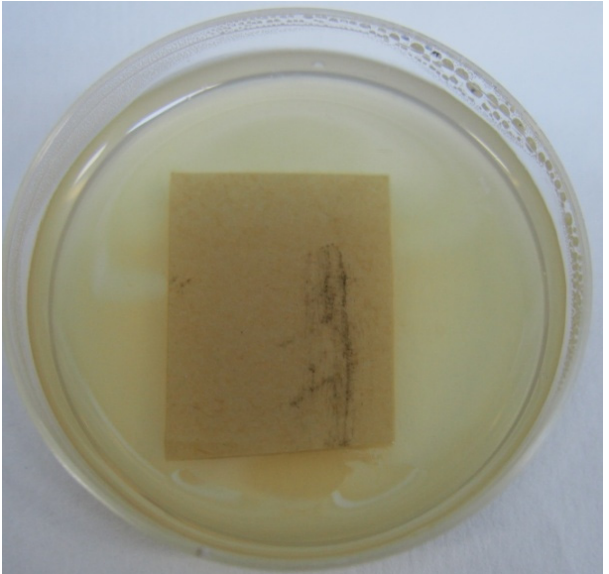

(e)

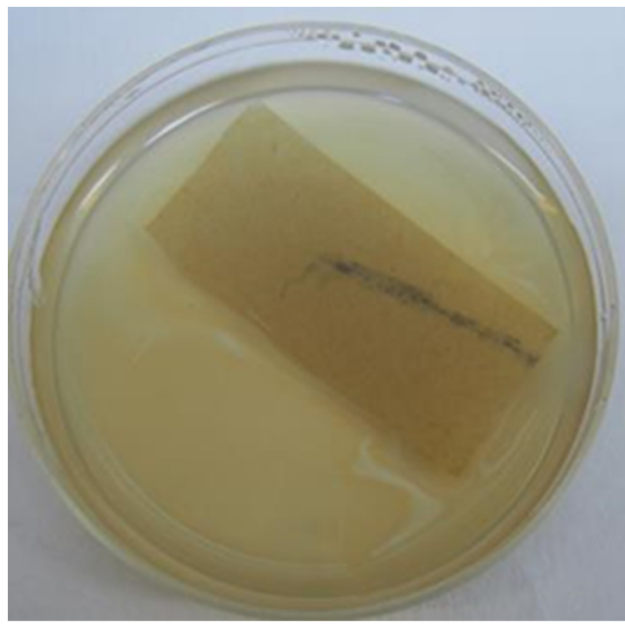

(b)

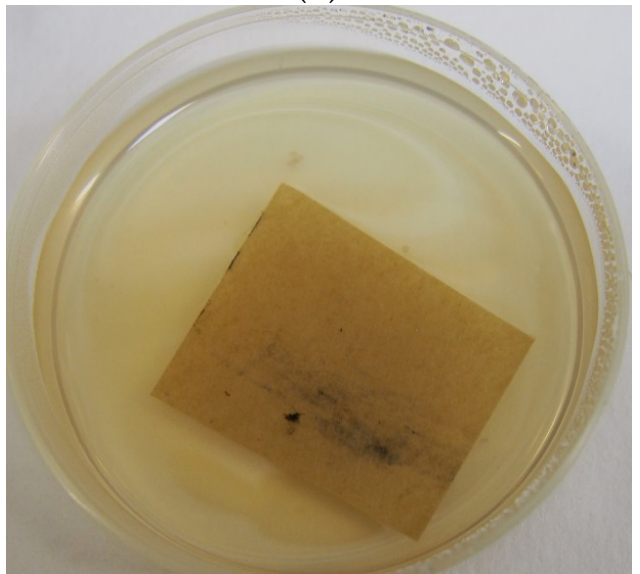

(d)

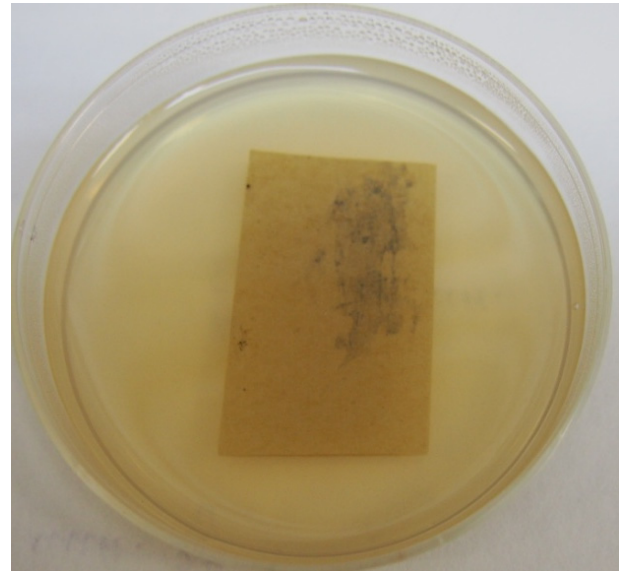

(f)

Figure 1. Antifungal effect of aerosol treatment by Rocima GT, depending on the exposure time (typographical printing paper): (a) control (treatment was not carried out); (b) $-5 \mathrm{~min}$; (c) — $10 \mathrm{~min}$; (d) $-15 \mathrm{~min}$; (e)-20 $\mathrm{min}$; (f) $-30 \mathrm{~min}$. 


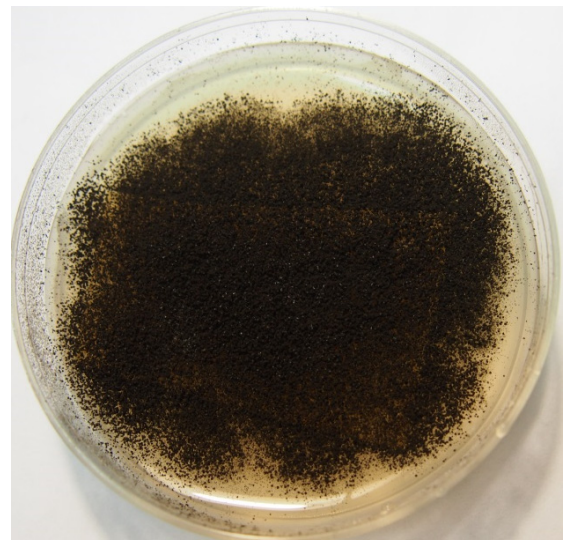

(a)

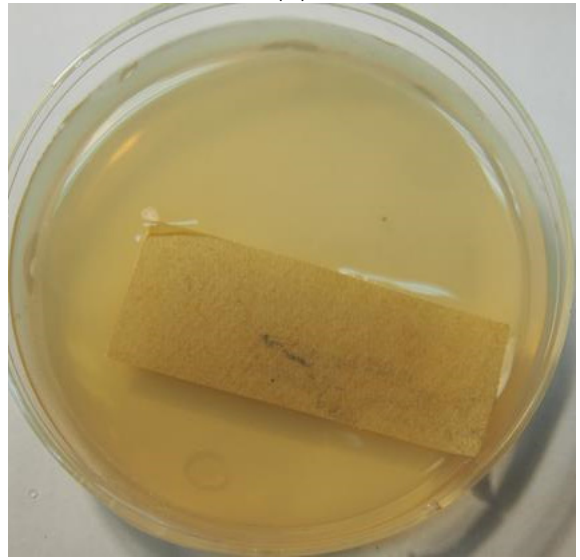

(c)

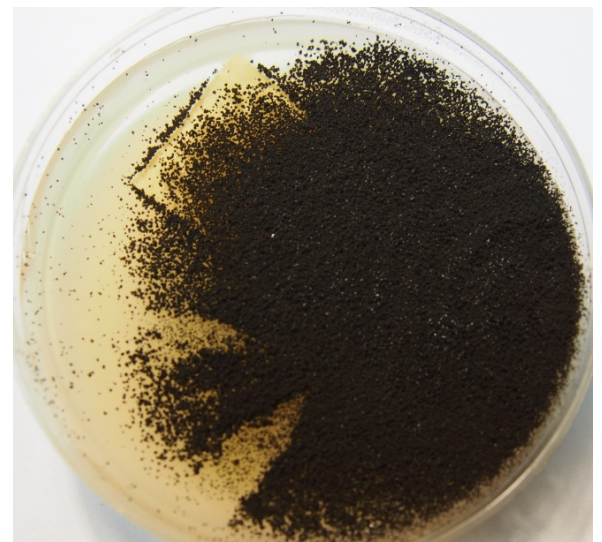

(b)

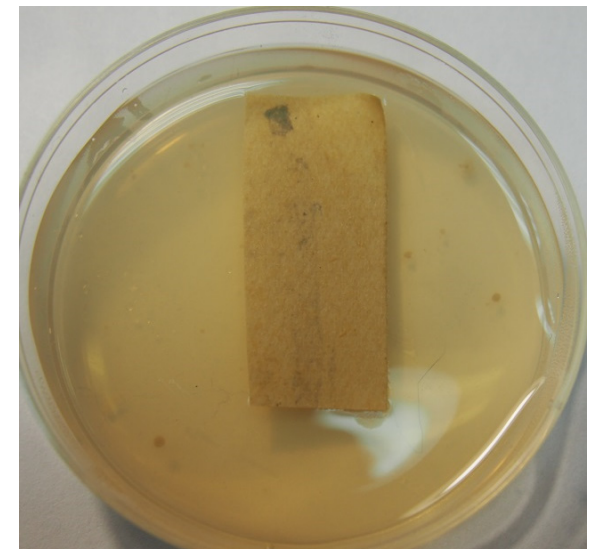

(d)

Figure 2. Samples of paper inoculated by A. niger on the 30th day of incubation after aerosol treatment by Rocima GT (typographical printing paper): (a) control (treatment was not carried out); (b) treatment by $5 \mathrm{~min}$; (c) treatment by $15 \mathrm{~min}$; (d) treatment by $30 \mathrm{~min}$.

After thermal aging, a decrease in the fracture resistance index was observed in the treated samples of paper made of sulfate cellulose (B-5) up to 30\%). Samples from the cotton half-mass (B-25) showed a tendency towards a slight increase in this indicator. For specimens made of sulfate cellulose (B-19) that were subjected by thermo-aging, the value of the fracture resistance index practically did not change. This applies to paper samples that have undergone either an aqueous treatment with a Rocima GT solution (by using swab) or treatment in the Rocima GT "vapors." The whiteness of all three types of paper after various treatments either decreased insignificantly or remained unchanged. The decrease in the whiteness of various types of paper after heat aging did not depend on the antifungal treatment method and corresponded to the whiteness of paper without treatment after heat aging. 
Table 1. Indicators to breakage resistance and whiteness of paper after various types of treatments.

\begin{tabular}{|c|c|c|c|c|c|c|c|}
\hline \multirow{3}{*}{ 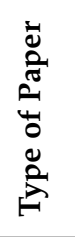 } & \multirow{3}{*}{ 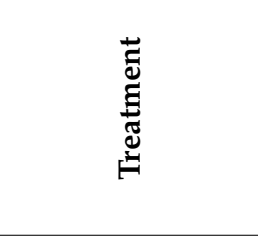 } & \multicolumn{2}{|c|}{ Break Resistance (h.p.) } & \multirow{3}{*}{ 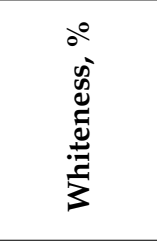 } & \multicolumn{3}{|c|}{ Thermo-Aging } \\
\hline & & \multirow{2}{*}{ Longitudinal } & \multirow{2}{*}{ Transverse } & & \multicolumn{2}{|c|}{ Break Resistance (h.p.) } & \multirow{2}{*}{ 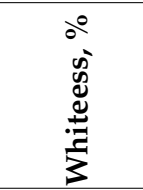 } \\
\hline & & & & & Longitudinal & Transverse & \\
\hline B-5 & \multirow{3}{*}{$\begin{array}{l}\text { without } \\
\text { treatment }\end{array}$} & $11.6 \pm 2.4$ & $32.6 \pm 3.9$ & $71.8 \pm 0.2$ & $8.9 \pm 1.7$ & $19.0 \pm 4.8$ & $69.0 \pm 0.0$ \\
\hline B-19 & & $165.5 \pm 36.3$ & $92.3 \pm 18.4$ & $72.2 \pm 0.3$ & $187.8 \pm 33.0$ & $88.8 \pm 13.5$ & $70.0 \pm 0.0$ \\
\hline B-25 & & $10.1 \pm 1.1$ & $7.2 \pm 0.4$ & $85.0 \pm 0.0$ & $11 \pm 1.0$ & $8.1 \pm 1.3$ & $84.0 \pm 0.0$ \\
\hline B-5 & \multirow{3}{*}{ distilled water } & $21.4 \pm 3.4$ & $30.1 \pm 5.0$ & $71.2 \pm 0.3$ & $16.8 \pm 6.2$ & $33.6 \pm 4.7$ & $69.0 \pm 0.0$ \\
\hline B-19 & & $161.5 \pm 29.3$ & $86.0 \pm 12.5$ & $70.0 \pm 0.0$ & $189.5 \pm 39.5$ & $135.5 \pm 30.1$ & $70.0 \pm 0.0$ \\
\hline B-25 & & $8.9 \pm 0.6$ & $6.5 \pm 0.5$ & $83.0 \pm 0.0$ & $10.3 \pm 0.9$ & $8.2 \pm 0.8$ & $84.0 \pm 0.0$ \\
\hline B-5 & \multirow{3}{*}{$\begin{array}{l}0.5 \% \text { aqueous } \\
\text { solution of } \\
\text { Rocima GT }\end{array}$} & $16.3 \pm 3.2$ & $24.4 \pm 4.7$ & $69.0 \pm 0.6$ & $15.1 \pm 3.5$ & $22.1 \pm 4.7$ & $69.0 \pm 0.0$ \\
\hline B-19 & & $86.1 \pm 17.9$ & $48.3 \pm 4.5$ & $69.0 \pm 0.6$ & $110.3 \pm 18.8$ & $48.1 \pm 7.7$ & $70.0 \pm 0.0$ \\
\hline B-25 & & $6.2 \pm 0.4$ & $5.2 \pm 0.4$ & $82.7 \pm 0.3$ & $7.4 \pm 0.7$ & $6.4 \pm 0.5$ & $84.0 \pm 0.0$ \\
\hline B-5 & \multirow{3}{*}{$\begin{array}{c}2 \% \text { aqueous } \\
\text { solution of } \\
\text { Rocima GT }\end{array}$} & $12.5 \pm 1.5$ & $19.7 \pm 2.8$ & $70.3 \pm 0.3$ & $9.9 \pm 1.5$ & $15.5 \pm 1.6$ & $70.0 \pm 0.2$ \\
\hline B-19 & & $46.4 \pm 7.3$ & $24.7 \pm 2.9$ & $69.5 \pm 0.0$ & $62.5 \pm 17.3$ & $33.6 \pm 6.6$ & $69.0 \pm 0.0$ \\
\hline B-25 & & $4.9 \pm 0.3$ & $4.0 \pm 0.0$ & $84.0 \pm 0.0$ & $5.8 \pm 0.4$ & $4.9 \pm 0.3$ & $84.0 \pm 0.0$ \\
\hline B-5 & \multirow{3}{*}{ water mist } & $18.7 \pm 2.6$ & $34.3 \pm 7.3$ & $69.0 \pm 0.0$ & $10.6 \pm 2.7$ & $22.8 \pm 2.9$ & $70.0 \pm 0.1$ \\
\hline B-19 & & $211.1 \pm 43.5$ & $110.9 \pm 26.9$ & $70.0 \pm 0.0$ & $189.6 \pm 51.4$ & $125.4 \pm 22.4$ & $68.8 \pm 0.7$ \\
\hline B-25 & & $10.6 \pm 1.0$ & $6.2 \pm 0.4$ & $84.0 \pm 0.0$ & $11.0 \pm 1.9$ & $8.1 \pm 0.6$ & $84.0 \pm 0.0$ \\
\hline B-5 & mist of $5 \%$ & $17.6 \pm 5.1$ & $23.0 \pm 2.8$ & $70.5 \pm 0.0$ & $7.0 \pm 1.0$ & $22.2 \pm 4.8$ & $70.0 \pm 0.0$ \\
\hline B-19 & aqueous solution & $168.5 \pm 54.0$ & $30.2 \pm 7.0$ & $70.0 \pm 0.0$ & $152.5 \pm 49.1$ & $41.5 \pm 6.9$ & $68.5 \pm 0.0$ \\
\hline B-25 & of Rocima GT & $7.4 \pm 0.6$ & $5.2 \pm 0.4$ & $84.0 \pm 0.0$ & $10.3 \pm 1.2$ & $8.1 \pm 0.9$ & $84.0 \pm 0.0$ \\
\hline
\end{tabular}

\subsection{Effect of Rocima GT on Organic Acids Produced by A. niger}

Rocima GT added in the liquid Czapec-Dox medium suppressed the growth of $A$. niger. For the A. niger growth suppression by $10 \%$, the Rocima GT concentration was $0.01 \%$; for growth suppression by $50 \%$, the Rocima GT concentration was $0.05 \%$, and for growth suppression by $80 \%$, the Rocima GT concentration was $0.1 \%$.

The sporulation of $A$. niger was inhibited under all concentrations of Rocima GT used. At high concentrations of Rocima GT, $0.05 \%$ and $0.1 \%$, the growth of the mycelium occurred mainly by pellets, and the surface mycelium film was not formed.

On the eighth day of growth, oxalic, citric, succinic, fumaric, malic, and gluconic acids were identified in the culture liquid of $A$. niger grown on a medium without biocides. The effect of Rocima GT on the production of organic acids by A. niger was manifested in different ways, depending on the concentration of the fungicide in the nutrient medium (Table 2). At $0.01 \%$ Rocima GT suppressed the formation of oxalic acid and had virtually no effect on the formation of other organic acids. At $0.05 \%$ Rocima GT, the oxalic acid content increased by 1.6 times. The amount of citric acid under the influence of the fungicide and in the control did not change significantly, while for fumaric, succinic, and malic acids, tendencies to decrease were observed. At $0.1 \%$ Rocima GT, the production of all organic acids was inhibited. 
Table 2. Effect of Rocima GT on organic acid production by A. niger.

\begin{tabular}{|c|c|c|c|c|c|c|}
\hline \multirow{2}{*}{$\begin{array}{c}\text { Rocima GT } \\
\text { Concentration, \% }\end{array}$} & \multirow{2}{*}{$\begin{array}{c}\text { Growth } \\
\text { Suppression, \% }\end{array}$} & \multicolumn{5}{|c|}{ The Amount of Organic Acids, mg/g Mycelium } \\
\hline & & Oxalic Acid & $\begin{array}{l}\text { Citric } \\
\text { Acid }\end{array}$ & $\begin{array}{c}\text { Fumaric } \\
\text { Acid }\end{array}$ & $\begin{array}{l}\text { Succinic } \\
\text { Acid }\end{array}$ & $\begin{array}{l}\text { Malic } \\
\text { Acid }\end{array}$ \\
\hline $0 \%$ (control) & 0 & $125.0 \pm 34.8$ & $\begin{array}{c}6.8 \pm \\
2.5\end{array}$ & $0.8 \pm 0.3$ & $1.5 \pm 0.7$ & $1.7 \pm 0.6$ \\
\hline $0.01 \%$ & 10 & $20.0 \pm 6.2$ & $\begin{array}{c}8.0 \pm \\
2.8\end{array}$ & $1.0 \pm 0.3$ & $1.0 \pm 0.4$ & $1.1 \pm 0.3$ \\
\hline $0.05 \%$ & 50 & $194.8 \pm 28.7$ & $\begin{array}{c}8.1 \pm \\
2.3\end{array}$ & $0.3 \pm 0.1$ & $0.4 \pm 0.2$ & $0.8 \pm 0.3$ \\
\hline $0.1 \%$ & 80 & $-*$ & - & - & - & - \\
\hline
\end{tabular}

\section{Discussion}

The results indicate the method based on chemical misting of paper using an aqueous solution of Rocima GT by ultrasonic fogging provides a good antifungal effect and, with a short exposure time, a fungistatic effect. The fungistatic effect of the Rocima GT solution mist is observable after $5 \mathrm{~min}$ of treatment. However, a longer exposure is required for the fungicidal effect. At the selected concentration of $5 \%$ Rocima GT solution, the minimum treatment time that ensures the complete disinfection of paper is $15 \mathrm{~min}$.

At the same time, the treatment of paper made of sulphite cellulose and cotton halfmass with a cold mist of a 5\% aqueous solution of Rocima GT leads to a lower decrease in the paper's strength than treatment with an aqueous solution of $0.5 \%$ and $2 \%$. This shows the advantage of this method compared to disinfection by the application of a swab saturated in a biocide aqueous solution.

The scope of the biocide is very wide, but the use of Rocima GT for the disinfection of cultural heritage is not very common today. Nevertheless, the studies [31], as well as our study, have shown the relative efficacy of the use of Rocima GT for paper disinfection.

According to our data, using this biocide should be related to Rocima GT having both a stimulating and an inhibitory effect on the acid production activity of $A$. niger, depending on the concentration. The A. niger strain cultivated on a Chapec-Dox media produces oxalic, citric, succinic, malic, and fumaric acids.

Organic acids are among the most aggressive fungal metabolites in relation to many materials, including paper. As paper is highly susceptible to acidic hydrolysis, acid production represents an important biodeterioration potential $[5,15]$. The acids' production of fungi can damage paper not only due to a low $\mathrm{pH}$; among all the acids secreted by fungi, the strongest oxalic acid is able to form insoluble salts-oxalates with di and trivalent metal. There is evidence that $\mathrm{CaCO}_{3}$-containing paper susceptible to fungal growth accumulates calcium oxalate, along with the disappearance of carbonate [43].

In general, the biocide suppressed the formation of organic acids by the fungus. However, $\mathrm{IC}_{50}$ Rocima GT $(0.05 \%)$ had a stimulation effect on the productivity of oxalic acid by $A$. niger. Nevertheless, it should be kept in mind that we are talking about the productivity of acid formation, i.e., when the growth of mycelium is suppressed by $50 \%$, the total amount of acid released is less than in the control. Perhaps, in this case, oxalic acid can help maintain the integrity of the membranes and, accordingly, greater resistance to the action of a biocide, which is consistent with the hypothesis of the role of oxalic acid in maintaining membrane stability [44]. Most likely, the decrease in the production of citric, malic, fumaric, and succinic acids in fungi under the action of Rocima GT is associated with their general inhibitory effect on the growth and processes of the energy metabolism of fungi.

It should be noted that the production of organic acids by fungi is a very labile process by default and is influenced by a lot of different factors. The change in acid production under various influences, including biocides, will differ mainly depending on the species and even the strains of fungi [17] 
In addition to the possible increase in the oxalic acid production under the action of Rocima GT, the effect of low concentrations of biocides, including Rocima GT, contributes to a fairly rapid formation of fungal resistance to the fungicide. The formation of resistant strains requires an increase in the used concentrations of biocides or the use of new ones [25].

Thus, the choice of the optimal concentration sufficient for the complete antifungal effect is one of the most important factors for the successful disinfection of paper and other materials.

When disinfecting with a cold mist of Rocima GT aqueous solution, fungal spores die; however, upon further storage, the fungicidal effect is lost. Disinfection by swab shows the same trend. The lack of preservation of the fungicidal effect over time could be problematic.

The issue of the short-term effect of some biocides was also noted in other studies, including the development of the chamber methods of disinfection by a chemical mist of quaternary ammonium salts [26]. If proper storage conditions are not observed, treatment does not protect against secondary contamination of fungal spores and subsequent damage to documents.

The disinfection should be used only on the basis of a preliminary mycological examination of documents and an estimation of the threat to document safety. Preventive treatment by biocide, less prolonged fumigation, and at a lowered concentration of the active substance are not desirable.

\section{Conclusions}

The results of this study indicate that the method of the chamber fumigation of paper by a Rocima GT solution mist is promising. This method will allow the antifungal treatment of a large volume of archival papers. In addition, the chemical mist treatment does not deform the paper. Research of this method of disinfection using Rocima GT and other water-soluble biocides will be continued for introduction in the practice of conservation and restoration measures in archives and libraries.

Author Contributions: Conceptualization, A.A.G. and K.V.S.; methodology, A.A.G. and A.I.A.; validation, K.V.S.; investigation, K.V.S., A.D.V., E.G.H., T.S.T., and I.M.P.; writing-original draft preparation, K.V.S.; writing—review and editing, E.G.H., A.D.V., A.A.G. and I.M.P.; visualization, K.V.S. All authors have read and agreed to the published version of the manuscript.

Funding: GC-MS analysis was funded by the Grant of the President of the Russian Federation for the state support of young Russian scientists, MK-799.2021.1.4 ("The metabolomics of communities of microorganisms of lithobiontic systems").

Institutional Review Board Statement: Not applicable.

Informed Consent Statement: Not applicable.

Data Availability Statement: Not applicable.

Conflicts of Interest: The authors declare no conflict of interest.

\section{References}

1. Oetari, A.; Natalius, A.; Komalasari, D.; Susetyo-Salim, T.; Sjamsuridzal, W. Fungal deterioration of old manuscripts of European paper origin. AIP Conf. Proc. 2018, 2023, 020156. [CrossRef]

2. Pinzari, F.; Pasquariello, G.; De Mico, A. Biodeterioration of Paper: A SEM Study of Fungal Spoilage Reproduced Under Controlled Conditions. Macromol. Symp. 2006, 238, 57-66. [CrossRef]

3. Sequeira, S.; Cabrita, E.J.; Macedo, M.F. Antifungals on paper conservation: An overview. Int. Biodeterior. Biodegrad. 2012, 74, 67-86. [CrossRef]

4. Sequeira, S.O.; Cabrita, E.J.; Macedo, M.F. Fungal Biodeterioration of Paper: How are Paper and Book Conservators Dealing with it? An International Survey. Restaurator 2014, 35, 181-199. [CrossRef]

5. Pinheiro, A.C.; Sequeira, S.O.; Macedo, M.F. Fungi in archives, libraries, and museums: A review on paper conservation and human health. Crit. Rev. Microbiol. 2019, 45, 686-700. [CrossRef]

6. Sterflinger, K. Fungi: Their role in deterioration of cultural heritage. Fungal Biol. Rev. 2010, 24, 47-55. [CrossRef]

7. Borrego, S.; Patricia, G.S.; Vivar, I.; Battistoni, P. Fungi involved in biodeterioration of documents in paper and effect on substrate. Acta Microsc. 2018, 27, 37-44. 
8. Lugauskas, A.; Krikŝtaponis, A. Microscopic Fungi Found in the Libraries of Vilnius and Factors Affecting their Development. Indoor Built Environ. 2004, 13, 169-182. [CrossRef]

9. Nitiu, D.S.; Mallo, A.C.; Saparrat, M.C.N. Fungal melanins that deteriorate paper cultural heritage: An overview. Mycologia 2020, 112, 859-870. [CrossRef]

10. Magnuson, J.K.; Lasure, L.L. Organic Acid Production by Filamentous Fungi; Plenum Publishers: New York, NY, USA, 2004; pp. 307-340.

11. Grbic, M.V.L.; Vukojevic, J.B. Role of fungi in biodeterioration process of stone in historic buildings. Proc. Natl. Acad. Sci. USA 2009, 116, 245-251.

12. Sequeda-Castañeda, L.G.; Ortiz-Ardila, A.E.; Correa-Cuadros, J.P.; López-Pérez, C. Chemical and microbiological comparison of biodeterioration in Colombian heritage constructions. Univ. Sci. 2013, 18, 51-63. [CrossRef]

13. Sazanova, K.V.; Frank-Kamenetskaya, O.V.; Vlasov, D.Y.; Zelenskaya, M.S.; Vlasov, A.D.; Rusakov, A.V.; Petrova, M.A. Carbonate and Oxalate Crystallization by Interaction of Calcite Marble with Bacillus subtilis and Bacillus subtilis-Aspergillus niger Association. Crystals 2020, 10, 756. [CrossRef]

14. Sturm, E.V.; Frank-Kamenetskaya, O.V.; Vlasov, D.Y.; Zelenskaya, M.S.; Sazanova, K.V.; Rusakov, A.V.; Kniep, R. Crystallization of calcium oxalate hydrates by interaction of calcite marble with fungus Aspergillus niger. Am. Miner. 2015, 100, 2559-2565. [CrossRef]

15. Sequeira, S.O.; Phillips, A.J.L.; Cabrita, E.J.; Macedo, M.F. Antifungal treatment of paper with calcium propionate and parabens: Short-term and long-term effects. Int. Biodeterior. Biodegrad. 2017, 120, 203-215. [CrossRef]

16. Baughan, E. (Ed.) Aspergillus niger. Pathogenicity, Cultivation and Uses; Nova Science Pub. Inc.: New York, NY, USA, 2020; 197p.

17. Sazanova, K.V.; Vlasov, D.Y.; Osmolovskay, N.G.; Schiparev, S.M.; Rusakov, A.V. Significance and regulation of acids production by rock-inhabited fungi. In Biogenic-Abiogenic Interactions in Natural and Anthropogenic Systems. Lecture Notes in Earth System Sciences; Springer Nature: Berlin/Heidelberg, Germany, 2016; pp. 379-392. [CrossRef]

18. Bennett, J.W.; Klich, M. Mycotoxins. In Encyclopedia of Microbiology, 3rd ed.; Moselio, S., Ed.; Academic Press: Oxford, UK, 2009; pp. 559-565. [CrossRef]

19. Pinheiro, A.C.; Macedo, M.F.; Jurado, V.; Saiz-Jimenez, C.; Viegas, C.; Brandao, J.; Rosado, L. Mold and yeast identification in archival settings: Preliminary results on the use of traditional methods and molecular biology options in Portuguese archives. Int Biodeterior. Biodegrad. 2011, 65, 619-627. [CrossRef]

20. Wiszniewska, M.J.; Walusiak-Skorupa, I.; Pannenko, M.; Draniak, M.; Paczyski, C. Occupational exposure and sensitization to fungi among museum workers. Occup. Med. 2009, 59, 237-242. [CrossRef]

21. Singh, J.; Yu, C.W.F.; Kim, J.T. Building Pathology, Investigation of Sick Buildings Toxic Molds. Indoor Built. Environ. 2010, 19, 40-47. [CrossRef]

22. Micalli, O.; Montacutelli, R.; Tarsitani, G. Pathogenic microorganisms and situations of risk to man. In Cultural Heritage and Aerobiology; Kluwer Academic Publishers: Dordrecht, The Netherlands, 2003; pp. 31-43. [CrossRef]

23. Khan, A.A.H.; Karuppayil, S.M.; Manoharachary, C.; Kunwar, I.K.; Waghray, S. Isolation, identification and testing for allergenicity of fungi from air-conditioned indoor environments. Aerobiologia 2009, 25, 119-123. [CrossRef]

24. Nyuksha, Y.P. Biological Damage to Paper and Books; Publishing house of the Russian Academy of Sciences: Saint-Petersburg, Russia, 1994; 210p. (In Russ)

25. Nitte'rus, M. Ethanol as fungal sanitizer in paper conservation. Restaurator 2000, 21, 101-115. [CrossRef]

26. Gutarowska, B.; Pietrzak, K.; Skóra, J. Disinfection as a factor reducing microbial threat at workposts in museum and library-A comparison of the effectiveness of photocatalytic ionization, UV irradiation and chemical misting. Int. J. Curr. Microbiol. Appl. Sci. 2014, 3, 945-959.

27. Xu, J.; Bai, Y.; Wan, M.; Liu, Y.; Tao, L.; Wang, X. Antifungal Paper Based on a Polyborneolacrylate Coating. Polymers 2018, 10, 448. [CrossRef] [PubMed]

28. Rakotonirainy, M.; Fohrer, F.; Flieder, F. Research on fungicides for aerial disinfection by thermal fogging in libraries and archives Int. Biodeterior. Biodegrad. 1999, 44, 133e139. [CrossRef]

29. Gutarowska, B.; Rembisz, D.; Zduniak, K.; Skóra, J.; Szynkowska, M.; Gliscinska, E.; Koziróg, A. Optimization and application of the misting method with silver nanoparticles for disinfection of the historical objects. Int. Biodeterior. Biodegrad. 2012, 75, 167-175. [CrossRef]

30. Special Chem. The Material Selection Platform. Available online: https://coatings.specialchem.com/product/a-dow-rocima-gt. (accessed on 25 January 2022).

31. Velikova, T.; Trepova, E.; Rosen, T. The use of biocides for the protection of library documents: Before and now. In Science against Microbial Pathogens: Communicating Current Research and Technological Advances; Microbiology Series, Formatex; Formatex Research Center: Badajoz, Spain, 2011; Volume 1, pp. 152-159.

32. Ellis, M.B. More Dematiaceous Hyphomycetes; Commonwealth Mycological Institute: London, UK, 1976 ; p. 507.

33. De Hoog, G.S.; Guarro, J. Atlas of Clinical Fungi; CBS: Baarn, The Netherlands, 1995; p. 1160.

34. Stielow, J.B.; Lévesque, C.A.; Seifert, K.A. One fungus, which genes? Development and assessment of universal primers for potential secondary fungal DNA barcodes. Persoonia 2015, 35, 242-263. [CrossRef] [PubMed]

35. AMDIS. Available online: http://www.amdis.net/index.html (accessed on 15 November 2021).

36. UniChrom. Available online: http:/ / www.unichrom.com/unichrome.shtml (accessed on 15 November 2021). 
37. ISO (International Organization for Standardization). Paper-Determination of Folding Endurance; ISO 5626:1993; ISO: Geneva, Switzerland, 1993.

38. ISO (International Organization for Standardization). Paper and Board-Accelerated Ageing; ISO 5630-5:2008; ISO: Geneva, Switzerland, 2008.

39. Franke, W. Internationale Normung fur Papier und. Pappe. Wochenbl. Papierfabr 1974, 102, 175-177.

40. ISO (International Organization for Standardization). Paper, Board and Pulps-Measurement of Diffuse Blue Reflectance Factor-Part 1: Indoor Daylight Conditions (ISO Brightness); ISO 2470:1999ISO 2470-1:2016; ISO: Geneva, Switzerland, 2016.

41. Perrone, G.; Stea, G.; Epifani, F.; Varga, J.; Frisvad, J.C.; Samson, R.A. Aspergillus niger contains the cryptic phylogenetic species A. awamori. Fungal Biol. 2011, 115, 1138-1150. [CrossRef] [PubMed]

42. Hong, S.B.; Lee, M.; Kim, D.H.; Varga, J.; Frisvad, J.C.; Perrone, G.; Gomi, K.; Yamada, O.; Machida, M.; Houbraken, J.; et al. Aspergillus luchuensis, an industrially important black Aspergillus in East Asia. PLoS ONE 2013, 28, e63769. [CrossRef] [PubMed]

43. Pinzari, F.; Zotti, M.; De Mico, A.; Calvini, P. Biodegradation of inorganic components in paper documents: Formation of calcium oxalate crystals as a consequence of Aspergillus terreus Thom growth. Int. Biodeterior. Biodegr. 2010, 64, 499-505. [CrossRef]

44. Zheng, X.; Tian, S.; Meng, X.; Li, B. Physiological and biochemical responses in peach fruit to oxalic acid treatment during storage at room temperature. Food Chem. 2007, 104, 156-162. [CrossRef] 